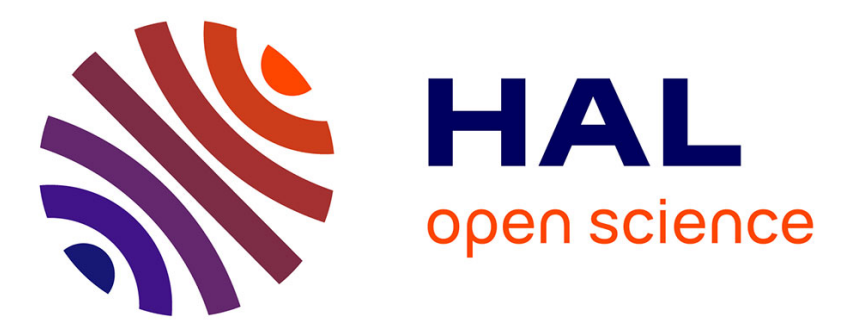

\title{
Estimation of local extreme suspended sediment concentrations in California Rivers
}

Yves Tramblay, André Saint-Hilaire, Taha B.M.J. Ouarda, Florentina Moatar, Barry Hecht

\section{- To cite this version:}

Yves Tramblay, André Saint-Hilaire, Taha B.M.J. Ouarda, Florentina Moatar, Barry Hecht. Estimation of local extreme suspended sediment concentrations in California Rivers. Science of the Total Environment, 2010, 408 (19), pp.4221-4229. 10.1016/j.scitotenv.2010.05.001 . insu-00509254

\section{HAL Id: insu-00509254 \\ https://hal-insu.archives-ouvertes.fr/insu-00509254}

Submitted on 9 Feb 2011

HAL is a multi-disciplinary open access archive for the deposit and dissemination of scientific research documents, whether they are published or not. The documents may come from teaching and research institutions in France or abroad, or from public or private research centers.
L'archive ouverte pluridisciplinaire HAL, est destinée au dépôt et à la diffusion de documents scientifiques de niveau recherche, publiés ou non, émanant des établissements d'enseignement et de recherche français ou étrangers, des laboratoires publics ou privés. 


\title{
Estimation of local extreme suspended sediment concentrations in California Rivers
}

\author{
Yves Tramblay ${ }^{\mathrm{a}}, \underline{\mathrm{b}}, \underline{\text {, }}$, André Saint-Hilaire ${ }^{\underline{\mathrm{a}}, \underline{\mathrm{e}}}$, Taha B.M.J. Ouarda ${ }^{\mathrm{a}}$, Florentina Moatar ${ }^{\mathrm{c}}$ \\ and Barry Hecht ${ }^{\underline{d}}$
}

${ }^{a}$ Chair in Statistical Hydrology, INRS-ETE, 490 rue de la couronne, Québec, Canada G1K9A9

${ }^{\mathrm{b}}$ Hydrosciences-Montpellier (UMR 5569), Université Montpellier 2, place Eugène Bataillon, 34095 Montpellier Cedex 5, France

${ }^{\mathrm{c}}$ Institut des Sciences de la Terre d'Orléans, (UMR6113), Parc de Grandmont, 37200 Tours, France

${ }^{\mathrm{d}}$ Balance Hydrologics, 800 Bancroft Way, Berkeley, California, 94710, USA

${ }^{\mathrm{e}}$ Canadian Rivers Institute, University of New Brunswick, Fredericton, N.B., Canada

\begin{abstract}
The total amount of suspended sediment load carried by a stream during a year is usually transported during one or several extreme events related to high river flow and intense rainfall, leading to very high suspended sediment concentrations (SSCs). In this study quantiles of SSC derived from annual maximums and the 99th percentile of SSC series are considered to be estimated locally in a site-specific approach using regional information. Analyses of relationships between physiographic characteristics and the selected indicators were undertaken using the localities of 5-km radius draining of each sampling site. Multiple regression models were built to test the regional estimation for these indicators of suspended sediment transport. To assess the accuracy of the estimates, a Jack-Knife re-sampling procedure was used to compute the relative bias and root mean square error of the models. Results show that for the 19 stations considered in California, the extreme SSCs can be estimated with 40-60\% uncertainty, depending on the presence of flow regulation in the basin. This modelling approach is likely to prove functional in other Mediterranean climate watersheds since they appear useful in California, where geologic, climatic, physiographic, and land-use conditions are highly variable.
\end{abstract}

Keywords: Extreme suspended sediment concentration; Regional estimation; California; Frequency analysis

\section{Introduction}

Extreme suspended sediment concentrations (SSCs) affect water quality (Waters, 1995) and can be a threat to aquatic life, although sustained lower levels of SSCS may also be a great problem (Newcombe, and J ensen, 1996). Estimation of SSCs is essential for characterising water quality and water resources management ([Achite and Ouillon, 2007] and [Gao et al., 2007]). It is also necessary in the case of an ungauged stream for establishing criteria for the maximum daily amount of sediment a stream can receive and still meet the water quality standards (i.e. 
maximum concentrations or total maximum daily loads, TMDLs). Since the number of sediment monitoring stations in the USA has decreased by 65\% from 1982 to 1998 (Gray and Glysson, 2002), reliable estimation methods are necessary to palliate the paucity of on-site measurements.

In California, the west coast is subjected to a Mediterranean type climate where river discharge is driven by seasonal winter rainfall and prone to episodic sediment production (Hecht, 1993). Whereas some more mountainous Californian rivers are influenced by snowmelt, such as the Santa Ana River. There is a strong seasonal cycle with almost all of the annual precipitation occurring between November and April (Ahearn et al., 2005) which produces ephemeral, torrential discharges in creeks and rivers of this region (Warrick et al., 2004). The sediment budget is mainly dominated by suspended sediment and the total amount of suspended load carried by a stream during a year is usually transported during one or few extreme events related to flood and intense rainfall ([Inman and Jenkins, 1999], [Cherifi and Loudiki, 1999] and [Meybeck et al., 2003]). Several studies have shown the importance of the quantitative role of rare or extreme events on the long-term average flux of suspended sediments especially for relatively small rivers ([Meade et al., 1990], [Meybeck et al., 2003] and [Rovira and Batalla, 2006]). In California, Kroll (1975) noted that half of the suspended sediment load in the Santa Maria River and the Santa Ana watersheds during a 40-year period ending in 1971 were transported during as few as the peak 10 days of the four decades. Warrick et al. (2004) observed for the Santa Clara River that more than half of the annual sediment load is carried during the top $1-5$ days of flooding.

The estimation of suspended sediment concentration and subsequent load estimation is usually done with rating curves between sediment concentrations and discharge. (Fergusson, 1986), (Asselman, 2000) and (Horowitz, 2003) has shown that these models tend to underestimate high SSCs. Quilbé et al. (2006) reported significant differences in the load estimates derived from discharge depending on the method used. Dodds and Whiles (2004) observed that discharge was moderately successful at predicting suspended sediment and Tramblay et al. (2008) found significant correlations between extreme SSCs and discharge only for 92 stations out of 179 in North America. This indicates that SSCs is often supply limited instead of transport limited.

The physical and anthropogenic factors controlling sediment availability and transport could interact differently in each event. Langlois et al. (2005) observed in a mountain stream near Lake Tahoe (Nevada) no clear relationship between stream discharge and SSC peaks, even when the event data were subdivided in terms of rising or falling stage. For small streams, there is often a weak correlation between water discharge and SSCs, whereas better correlations can be observed for moderate to larger rivers (Morehead et al., 2003). The dynamics in small creeks are such that perturbations (urbanisation, land-use change, slope failures, forest fires, earthquakes, etc.) can easily affect the relationship between water discharge and SSCs by generating outliers. Overall, in Mediterranean regions, several studies reported a high degree of scatter in the SSC/discharge relation, illustrated by no significant or little correlations, leading to sediment rating curves that can substantially underestimate or overestimate the concentrations ([Rovira and Batalla, 2006], [Alexandrov et al., 2007], [Nadal-Romero et al., 2007], [Soler et al., 2007a] and [Zabaleta et al., 2007]).

Aside from discharge, several correlations have been established between watershed characteristics (including topography, geology, climate, and land use) and sediment yield ([Ludwig and Probst, 1998] and [Restropo et al., 2006]), mean SSC values ([Jarvie et al., 
2002], [Robertson et al., 2006], [Siakeu et al., 2004] and [Dodds and Whiles, 2004]) or extreme SSCs (Tramblay et al., 2010). Modelling attempts of sediment yield have been carried out using regression with watershed characteristics by (Ferraresi, 1990), (Bray and Xie, 1993 ) and (Restropo et al., 2006). Mimikou (1990) proposed a regional estimation of the rating curve parameters based on physiographic attributes. For SSCs, Robertson et al. (2006) used a regression tree analysis in the Great Lakes region in order to estimate several water quality parameters, including SSCs, from soils and land cover data. Ahearn et al. (2005), in their study about the impact of land use on weekly samples of sediment transport in Sierra Nevada, reported that many studies linked land use to river water quality indicators, but none have been conducted in Californian watersheds.

The importance of the local characteristics of a particular measuring site for suspended sediment transport characterization and estimation has been previously investigated for mean SSCs in [Jarvie et al., 2002] and [Siakeu et al., 2004]. The usefulness of establishing sitespecific sediment sampler calibration or suspended sediment/discharge rating curves has been demonstrated by (Asselman, 2000) and (Horowitz, 2003). Tramblay et al. (2008) observed that the best probability distributions fitting annual maximum SSCs were varying from one river to another, even within a short distance. The high site-specificity feature of suspended sediment transport has been discussed in several previous studies (Meade et al., 1990), but has not been yet studied nor quantified for extreme SSCs. Suspended sediment transport might be closely linked to the availability of local sources of sediment, as previously stated by Jarvie et al. (2002) for mean SSCs.

In this study, an approach is developed to estimate extreme SSCs for unmonitored sites, using a similar method to the one used for flood estimation in ungauged sites. The approach consists in two steps: the local modelling of extreme SSCs at gauged sites and the regional estimation of extreme SSCs in order to build a model usable for ungauged basins. First, extreme SSCs are modelled for stations with observational SCC data, using a frequency analysis approach to estimate the magnitude of SSCs for different return periods. Only a few studies have considered a probabilistic modelling approach for SSCs, some applications could be found in (Van Sickle, 1982), (Watts et al., 2003), (Simon et al., 2004), (Soler et al., 2007b) and (Simon and Klimetz, 2008). The frequency analysis for annual maxima of SSCs in North America is described in detail by Tramblay et al. (2008). The same methodology was used in the present study to estimate SSC quantiles corresponding to various return periods.

The second step is the estimation of extreme SSCs at sites with no data. In flood regionalisation, the flood quantiles are usually estimated using the physiographic characteristics of the entire watersheds. In this study, the estimation of SSC quantiles is carried out with a site-focused approach. The physiographic characteristics were not considered at the watershed scale but only for a sub-portion of it; the locality of the stations, here defined by the $5 \mathrm{~km}$ radius draining to each sampling site. The physiographic characteristics of the locality were used to estimate extreme SSCs for various sites in west California.

\section{Datasets and methodology}

\subsection{Selection of stations in California}

Stations in California with 10 years or more of daily SSC and discharge data were selected from the U.S. Geological Survey (USGS) Sediment Database. The uniform data collection 
methods developed by the USGS provide comparable data between the stations. The daily mean concentration is a time-weighted mean value (Porterfield, 1972); with a sampling frequency usually increased during high flow periods. Since hydrologic sampling can be hazardous during extreme events such as floods, extreme values of hydrological properties could be subjected to large uncertainties. Detailed information about sampling protocols and data collection can be found in Edwards and Glysson (1988).

Impoundment due to reservoirs, influences the flow regime of most of the rivers in California. However, these impacts are deemed necessary to fulfil the social demands for irrigation and water supply. The database of the National Inventory of Dams (NID) from the US Army Corps of Engineers and metadata from USGS stations database were used to detect the presence of dams or reservoirs in the selected river basins. Fully regulated rivers (i.e. station located immediately after a reservoir or mentioned as fully regulated in the station metadata) were excluded since sediment transport can be greatly affected by regulation in rivers ([Meade et al., 1990], [Snoussi et al., 2002] and [Walling, 2006]). Of 39 stations where long SSC records are available in California, 19 were selected to represent a mixture of hydrological conditions. 11 of them are located on streams either unregulated (San Diego or Redwood Creeks) or which have reservoirs on tributaries but not on their main stem (Santa Clara and Salinas Rivers). The second group consists of 8 streams with reservoirs on their main stem, at a distance of 18 to $178 \mathrm{~km}$ (Table 1) from the sampling station. The catchment sizes of the selected stations are ranging from 100 to $20,000 \mathrm{~km}^{2}$ (Table 1) and Fig. 1 shows their geographic localisation.

\subsection{Local physiographic characteristics}

Several layers of spatial information about elevation, land cover, soil types and climate were integrated in order to retrieve the characteristics listed in Table 2. The SRTM 4.1 digital elevation model (http://srtm.csi.cgiar.org) at a resolution of $30 \mathrm{~m}$ was used for elevation and slope data. Land cover was provided by the NLCD 1992 USGS database, with a 21-class land cover classification scheme over the United States. Soils data were extracted from the STATSGO (1994) database of USDA, including several descriptors of soils properties (Table 2). Climate data were retrieved from USHCN (NOAA) and stations with time series of 30 years or more were selected. Several climate indices were computed. These indices were selected from those defined by the STARDEX project (www.cru.uea.ac.uk/projects/stardex/). Days with precipitation (PRCP1) are the number of days per year with more than one millimetre of precipitation. Rainfall intensity (SDII) is the ratio of the total annual precipitation divided by the number of days with precipitation. Maximum daily precipitation (PDAYMAX) is the inter-annual mean of total precipitation of the wettest day of each year. All indices were averaged over 30 years of observation, and interpolated with ordinary kriging. Physiographic characteristics were extracted only for the $5 \mathrm{~km}$ locality of the sampling stations. The size of the locality was chosen to take into account the range of drainage areas of the stations considered in this study. The station-locality area is illustrated in Fig. 2. All parameters were spatially averaged within the boundaries of each station-locality.

\subsection{At-site frequency analysis of extreme SSCs}

For each station annual maxima of SSCs were extracted. The hypotheses of homogeneity, stationarity and independence were verified for all the series as a prerequisite for frequency analysis. The non-parametric tests of Wilcoxon for homogeneity, Wald-Wolfowitz for autocorrelation and Kendall for stationarity were used at the $1 \%$ significance level. Then 
series of annual maxima of SSCs were fitted with theoretical probability density functions to estimate local quantiles for different return periods. The complete methodology for this local frequency analysis is described in Tramblay et al. (2008). The selection of the most appropriate probability distribution was based on the lowest score of the Bayesian Information Criterion (BIC):

$\underline{\mathrm{BIC}}=-2 \log (L)+2 k \log (N)$

where $L$ is the likelihood function,

$k$ is the number of parameters and $N$ is the sample size.

\subsection{Regional estimation}

For regional estimation of quantiles, multiple linear regressions between quantiles and pysiographic characteristics were built. Direct log-linear regression with quantiles is the most common estimation approach in flood regionalisation (GREHYS, 1996). A relation between each quantile and physiographic characteristics of the watersheds of this form was established:

$$
C(T)=\xi_{0} V_{1}^{k_{1}} V_{2}^{\beta_{2}} \ldots V_{p}^{b_{25}} \ell^{6}
$$

where $C(T)$ is the quantile corresponding to a return period $T, \beta i$ are the parameters to estimate, $V_{i}$ are the explanatory variables and $e$ a normal error. The $\beta i$ parameters were estimated with the least square method after logarithmic transformation of Eq. (2). The explanatory variables were selected based on the correlations between the quantiles and physiographic characteristics using Spearman correlation coefficient. A forward stepwise regression procedure was used in order to optimize the number of significant explanatory variables.

\subsection{Assessment of the reliability of the regional estimations}

Estimation of the reliability of the regional estimates was performed using a leave-one-out resampling procedure to calculate error statistics. Every site is in turn considered ungauged and removed from the database. The remaining sites are then used to build a regression model to estimate the quantile at the station that has been removed. Then using the difference between the local quantile and the Jack-Knife estimate, it is possible to compute the relative bias (RBIAS), relative root mean square error (RRMSE) on the estimated quantiles for each site:

$$
\begin{aligned}
& \operatorname{RBLAS[0\% ]}=\frac{1}{N} \sum_{i=1}^{N}\left(\frac{C_{F}^{i}-C_{F}^{i}}{C_{F}^{i}}\right) \times 100 \\
& \operatorname{RRMSE[\% }[\%]=\sqrt{\frac{1}{N} \sum_{i=1}^{N}\left(\frac{C_{T}^{i}-C e_{T}^{i}}{C_{T}^{i}}\right)^{2}} \times 100
\end{aligned}
$$


where $C e_{T}{ }^{i}$ is the regionally estimated $T$-year quantile at site $i, C_{T}{ }^{i}$ the $T$-year local quantile at site $i$, and $N$ the number of sites in the region. These performance indicators were computed for each regional model built in this study to compare their efficiency.

\section{Results}

\subsection{Correlation between annual maximum SSCs and corresponding discharge}

The relation between extreme SSCs and discharge was investigated since it is traditionally the most common way to estimate SSCs. For each annual maximum of SSCs, the corresponding maximal discharge during the whole period covering 3 days prior and 3 days after the SSC event was extracted. On average, the lag time observed between the annual peak of SSCs and the corresponding event discharge is 1.7 days. For over half of the events $(55.06 \%)$, the peak of SSCs occurs the same day as peak flow. $28 \%$ of the events have the peak flow occurring before the peak of SSCs, showing a clockwise hysteretic effect, and $16.5 \%$ of events have an anti-clockwise hysteretic effect. The total number of events (for all stations) considered is 266 . A high degree of scatter can be seen in the relation between annual maximum SSCs and the corresponding discharge for several stations. For each station the correlation between annual maximum SSC event and the corresponding maximum discharge was evaluated using the Spearman correlation coefficient at the 5\% significance level. Results indicate that the correlation is significant in only 10 stations out of 19 (Table 3). Except for 3 stations, stations where the correlation is significant are sites where there is no lake or reservoir upstream or located on tributaries. For some rivers, such as the Eel River, a good relation between SSCs and water discharge can be observed when considering the whole range of observed values (Morehead et al., 2003) but no significant correlation when considering only the annual maximum SSCs and the corresponding discharge.

\subsection{Local frequency analysis of annual maximum SSCs}

Series of annual maximum SSCs were modelled with probability distributions. The complete list of tested distributions is available in Tramblay et al. (2008). For each station, the distribution with the lowest Bayesian information criteria (BIC) was selected. For eight stations, the annual maximum SSCs were fitted with log-normal and eight with exponential distributions, the three remaining series were fitted with Gamma distributions. The selected distributions show neither specific spatial pattern and are not a function of a specific land use, exhibiting the site-specificity feature of suspended sediment transport.

In order to study the correlations with physiographic characteristics and test the regional estimation, 3 quantiles of return period 2, 10 and 20 years $(\mathrm{C} 2, \mathrm{C} 10$ and $\mathrm{C} 20)$ were extracted from each fitted distribution. The quantile corresponding to the 2-year return period is, for most stations, equivalent to the median of the series of annual maximum SSCs. The Spearman correlation coefficient is 0.98 between the median of annual maximum SSCs and the quantile of SSCs corresponding to a 2-year return period. The other quantiles of longer return periods (10 and 20 years), characterising the less frequent events, are among the highest quantiles that can be extrapolated from the statistical distributions with a good confidence interval since the lengths of time series were small (the average record length is 13.6 years). In addition, the 99th percentile of the SSC distribution was also extracted from the station data series. 


\subsection{Variability of extreme SSCs}

Annual maximums of SSCs for the selected stations show a significant variation from year to year as well as a variation in space between stations. Fig. 3 shows the range of values of annual maximum SSCs for each station. The same variation is observed for the computed SSC quantiles, as shown by Fig. 4. The highest concentrations are found in the southern streams, frequently exceeding $10,000 \mathrm{mg} / \mathrm{L}$, whereas in northern streams the medians of annual maximum concentration are below $10,000 \mathrm{mg} / \mathrm{L}$. Calleguas and Sespe Creeks, Santa Clara River (station numbers 4, 5 and 6 on Fig. 3) are the streams exhibiting the greatest variation of the annual maximum values of SSCs. These are also the stations with the highest recorded concentrations; exceeding 20,000 mg/L. (Meade et al., 1990), (Inman and Jenkins, 1999) and (Warrick et al., 2004) previously reported very high sediment production rates for these southern Californian streams as well as very high SSCs during storm events.

To assess the influence of regulation structures or lakes that are significantly impacting the movement and storage of fine sediments, two groups of stations were analyzed distinctly. The first group consists of sites with no reservoir or lakes upstream on the main stem of the river. The second group consists in sites with a reservoir or a lake upstream of the station. Fig. 4 shows the 99th percentile of SSCs for the two groups of stations (group A and group B) and Fig. 5 the SSC quantiles for the same stations. There is no clear pattern associating the sites with reservoir or lakes with lower SSCs but on average it can be seen that stations of group A have larger values of SSCs measured than group B, both for the 99th percentile and the quantiles derived from the annual maximum. It is worth to notice the case of the Santa Ana River (station number 3) located $32 \mathrm{~km}$ downstream of Prado reservoir, but with extreme SSC magnitude equivalent to the surrounding unregulated sites.

\subsection{Correlations with station-locality characteristics}

The quantiles corresponding to return periods of 2, 10, 20 years (respectively C2, C10 and C20) and the 99th percentile (SSC99) of SSCs show several significant correlations with physiographic characteristics at the station-locality scale. Table 4 shows the Spearman correlation coefficients between extreme SSC indicators and station-locality characteristics. The statistically significant correlations at the 5\% confidence level are indicated in bold. There are no statistically significant correlations with water discharge quantiles Q2, Q10 and Q20. On the whole, the correlations are stronger with the SSC quantiles corresponding to longer return periods. Extreme SSCs are correlated with several land cover classes; a negative correlation with forest cover, and positive correlations with residential or commercial land use and different types of agricultural classes (Shrubland, Orchard/Vineyards, Pasture/Hay, Row Crop and Small Grains). This indicates that the presence of such agricultural land uses in the vicinity of the station could produce high SSCs. All topographic attributes, describing the altitude and slope, are correlated with extreme SSCs at the station-locality scale. There are also good correlations with annual precipitation and several soils attributes such as rock volume on the surface, permeability and drainage quality of the soils.

\subsection{Regional estimation of extreme SSCs}

A regression model was built using the attributes correlated with extreme SSC indicators. Stepwise regression algorithm was used in order to reduce the number of variables to be included in the regression models. The model built is: 


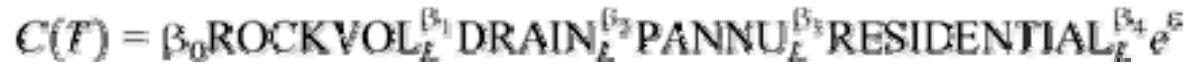

where $C(T)$ is the quantile corresponding to the return period $T$, or the percentile to estimate, $\beta i$ and $\theta i$ are the regression parameters and $e$ a normal error term. The model was used to proceed to the regional estimation of SSC quantiles C2, C10 and C20 and the 99th percentile of SSC series (SSC99). The estimation results in terms of RBIAS and RRMSE after JackKnife re-sampling, are presented in the Table 5 together with the coefficient of determination $\left(R^{2}\right)$. Uncertainties in the estimation are larger when considering short return periods such as 2 years $(\mathrm{C} 2)$. Fig. 6 shows the plot of the regional estimates versus the at-site values of the quantiles and the 99th percentile. For the 2 stations with the highest SSCs recorded, Calleguas Creek (11106550) and Santa Clara River (11108500), regional estimation tends to underestimate the concentration for all quantiles and the 99th percentile. Calleguas Creek is located in the rapidly urbanising Ventura County, near Los Angeles, where urbanisationinduced channel incision is profound (Coleman et al., 2005).

Considering all the 19 sites, estimation errors in terms of RRMSE are ranging from $48 \%$ to $60 \%$ for all indicators (Table 5). When dividing the results into two groups of stations according to their level of regulation (sites with no reservoir on the main river stem and sites with reservoirs upstream), one could see that the estimation performs better for the rivers that are less regulated, leading to lower RBIAS and RRMSE values ([Fig. 7] and [Fig. 8]). For sites located downstream a reservoir, the RBIAS is on average of $-25 \%$. For this group of stations, the extreme SSCs are overestimated (Fig. 7) when the physiographic characteristics are used in Eq. (5), as expected in the presence of dams or reservoir that traps sediments. For the other group of sites, much less impacted by flow regulation, the mean RBIAS is $0.2 \%$ with positive and negative values around zero that indicate no systematic bias. The difference of estimation performance for SSC quantiles and the 99th percentile between the two groups of sites is ranging from $17 \%$ to $41 \%$ of RRMSE (Fig. 8), on average the difference is $26 \%$ for all indicators considered in the study.

\section{Discussion}

Extreme rates and variability of suspended sediment transport were observed in the selected Californian streams in this study. The high inter-annual variability of the annual maximum SSCs adds uncertainty to the probabilistic modelling in absence of very long record for all stations. As observed by Meade et al. (1990), some extreme events may belong to different populations than the more typical year-to-year peak flows and therefore may not be predicable by extrapolation based on fitting a statistical distribution that is representative if the parent distribution of annual extremes that include mostly events of lesser amplitude. During their period of record (Table 1), SSCs were strongly affected by at least one flood event considered to a have a return period of several hundred years within 2 or 3 of the watersheds; sediment yields in all watersheds north of San Francisco were episodically increased by the floods of water year (WY) 1965, central California streams north of Los Angeles by floods of WY1969, and the three southern basins by WY1979 events. The large variability of sediment transport intrinsic to semi-arid watersheds (1 through 10) is shown clearly in Fig. 3. Nonetheless, SSCs at gauges north of San Francisco showed substantial higher variability due to residual disturbance of land cover associated with the WY1965 storm events and with massive timber harvests at a regional scale affecting large proportions of each northern watershed through the 1960s and 1970s. 
In addition to scatter imposed by semi-arid, disturbed, or episodic conditions, the estimation errors observed are probably in substantial part caused by the flow regulation and the databases used to retrieve the physiographic characteristics of the catchment and the stationlocality. As an example, there is no differentiation made in the database between mature forest lands or those recently harvested. The impact of flow regulation by dams, reservoirs or lakes on suspended sediment transport is hard to assess on a quantitative basis, which would require detailed technical specifications of the regulation structures. Different types of manmade or natural reservoirs may behave significantly differently in the way they interrupt the sediment transfer in the river and the storage of sediments.

Most of the suspended sediment data used in this study was collected before the 1990s (except for station 11525600 with records until 1994) while land use, derived from satellite images, and soil information databases were generated more recently. Higgitt and Lu (1999) showed that the first difficulty of assessing land-use impact on sediment delivery was caused by the time discrepancy between available SSC records and the physiographic data. It is hypothesized that several river basins considered in this study, in particular the ones close to urban areas, have had a significant modification in either their land use, or in the implementation of soil conservation and sediment control measures, leading to either an increase or a decrease in the supply of fine sediments (Walling, 2006). Another feature specific to these semi-arid catchments is the occurrence of wildfires that produce a large increase in sediment exports. Factor of 10 increases in SSCs are typical throughout coastal California south of San Francisco following fires, quickly diminishing after the first wet year (Hecht, 1993). In the case of Los Padres Reservoir, adjoining the Arroyo Seco catchment, detailed river bed habitat surveys showed that once nearly all post-fire suspended sediment had been flushed from the basin during the first year, the sediment load deposited was almost exactly equivalent to the load deposited during the previous 37 years since the construction of the dam (Hecht, 1981).

\section{Conclusions}

Extreme suspended sediment concentrations in Californian rivers show a great variability in space and time, and are correlated with several physiographic characteristics at the stationlocality scale. Of the 19 very diverse selected rivers considered in this study, extreme SSCs can be estimated with an accuracy of an average RRMSE of 54\% by applying a site-focused approach. Higher estimation errors and systematic negative bias are observed in the case of sampling sites located downstream of reservoirs or lakes on the main stem of the river, with an average increase of RRMSE of $26 \%$. This modelling approach could be applied to other Mediterranean climate watersheds, since its efficiency has been tested in the context of rivers in California with variable physiographic characteristics. This approach could also be used to estimate other SSC indicators, such as quantiles estimated using a peaks over threshold approach or duration/intensity indexes for water quality analysis.

The main conclusion that could be drawn from this work for future sediment regionalisation studies is the importance to consider the local physiographic and sediment-producing characteristics of the measuring stations. In future analysis, the land use and soil properties close to the river channel could also be analyzed. One should not focus solely on information gathered at the catchment scale, especially for large drainage basins. There is also a need to test different sizes of station-locality to define the optimal "locality" of a given gauging station for sediment transport characterization. Given the varied geology of coastal California, the "local" influence may be influenced by erodibility of particular units (including alluvium, 
especially where incised) or due to intrinsic properties of drainage basins or the scale of extreme SSC-generating events. Future studies should verify that the optimal station-locality size to characterise suspended sediment transport varies depending of the localization of the considered stations within the different climatic/geomorphologic regions.

\section{Acknowledgements}

The financial support provided by the Natural Science and Engineering Research Council of Canada (NSERC) and Hydro-Québec is gratefully acknowledged. The authors also whish to thank J. Poulin and C. Dieulin for technical support with GIS data processing. The authors also extend their thanks to Michel Meybeck, Albert Kettner, the executive editor, John G. Farmer, and the anonymous reviewers for their constructive comments and suggestions on the earlier draft of the paper.

\section{References}

Achite and Ouillon, 2007 M. Achite and S. Ouillon, Suspended sediment transport in a semiarid watershed, Wadi Abd, Algeria (1973-1995), J Hydrol 343 (2007), pp. 187-202.

Ahearn et al., 2005 D.S. Ahearn, R.W. Sheibley, R.A. Dahlgreen, M. Anderson, J. Johnson and K. Tate, Land use and land cover influence on water quality in the last free-flowing river draining the western Sierra Nevada, California, J Hydrol 313 (2005), pp. 234-247

Alexandrov et al., 2007 Y. Alexandrov, J.B. Laronne and I. Reid, Intra-event and interseasonal behaviour of suspended sediment in flash floods of the semi-arid northern Negev, Israel, Geomorphology 85 (2007), pp. 85-97.

Asselman, 2000 N.E.M. Asselman, Fitting and interpretation of sediment rating curves, $J$ Hydrol 234 (2000), pp. 228-248.

Bray and Xie, 1993 D.I. Bray and H. Xie, A regression method for estimating suspended sediment yields for ungauged watershed in Atlantic Canada, Can Civ Eng 20 (1993), pp. 8287.

Cherifi and Loudiki, 1999 O. Cherifi and M. Loudiki, Flood transport of dissolved and suspended matter in the El Abid river basin (Morocco), Hydrobiologia 410 (1999), pp. $287-$ 294.

Coleman et al., 2005 D. Coleman, C. McRae and E.D. Stein, Effect of increases in peak flows and imperviousness on the morphology of southern California streams, A report from the Stormwater Monitoring Coalition. Technical Report, Southern California Coastal Watershed Restoration (2005).

Dodds and Whiles, 2004 W.K. Dodds and M. Whiles, Quality and quantity of suspended particles in rivers: continental-scale patterns in the United States, Environ Manage 33 (2004), pp. 355-367.

Edwards and Glysson, 1988 T.K. Edwards and G.D. Glysson, Field methods for measurement of fluvial sediment: U.S. Geological Survey open-file report (1988), pp. 86-531. 
Fergusson, 1986 R.I. Fergusson, River loads underestimated by rating curves, Water Resour Res 22 (1986), pp. 74-76.

Ferraresi, 1990 M. Ferraresi, The regionalisation of fluvial sediment yield in Emilia-Romagna (Italy), Proceedings of the Ljubjana Symposium, IAHS Publication 191, Wallingford, UK (1990).

Gao et al., 2007 P. Gao, G.B. Pasternack, K.M. Bali and W.W. Wallender, Suspended sediment transport in an intensively cultivated watershed in southeastern California, Catena 69 (2007), pp. 239-252.

Gray and Glysson, 2002 J.R. Gray and G.D. Glysson, Introduction to the proceedings of the federal interagency workshop on turbidity and other sediment surrogates, Proceeding of Fifth Interagency Workshop on Turbidity and Other Sediment Surrogates (30 April-2 May 2002, Reno, USA), USGS, USA (2002).

GREHYS, 1996 GREHYS, Presentation and review of some methods for regional flood frequency analysis, J Hydrol 186 (1996), pp. 63-84.

Hecht, 1981 B. Hecht, Sequential changes in physical conditions affecting aquatic habitat in the upper Carmel River, California, following the Marble-Cone Fire of August 1977, Proceedings of the California Riparian Symposium, September 1981, University of California Press (1981).

Hecht, 1993 B. Hecht, South of the spotted owl - restoration strategies for episodic channels and riparian corridors in central California, Proceedings of the Society of Wetlands Scientists, Western Wetlands Conference, March 25-27, 1993, Davis, CA (1993).

Higgitt and Lu, 1999 D.L. Higgitt and X.X. Lu, Challenges in relating land use to sediment yield in the Upper Yangstze, Hydrobiologia 410 (1999), pp. 269-277.

Horowitz, 2003 A.J. Horowitz, An evaluation of sediment rating curves for estimating suspended sediment concentrations for subsequent flux calculation, Hydrol Process 17 (2003), pp. 3387-3409.

Inman and Jenkins, 1999 D.L. Inman and S.A. Jenkins, Climate change and the episodicity of sediment flux of small California Rivers, J Geol 107 (1999), pp. 251-270.

Jarvie et al., 2002 H.P. Jarvie, T. Oguchi and C. Neal, Exploring the linkages between river water chemistry and watershed characteristics using GIS-based catchment and locality analysis, Reg Environ Change 36 (2002), pp. 36-50.

$\underline{\text { Kroll, } 1975}$ C.G. Kroll, Estimate of sediment discharges, Santa Ana River at Santa Ana and Santa Maria River at Guadalupe, California: U.S. Geological Survey Water-Resources Investigations (1975), pp. 40-74.

Langlois et al., 2005 J.L. Langlois, D.W. Johnson and G.R. Mehuys, Suspended sediment dynamics associated with snowmelt runoff in a small mountain stream of Lake Tahoe (Nevada), Hydrol Process 19 (2005), pp. 3569-3580 
Ludwig and Probst, 1998 W. Ludwig and J.L. Probst, River sediment discharge to the oceans: present-day controls and global budgets, Am J Sci 298 (1998), pp. 265-295.

Meade et al., 1990 R.H. Meade, T.R. Yuzyk and T.J. Day, Movement and storage of sediment in rivers of the United States and Canada, Surface Water Hydrology, Geological Society of America, Boulder, Colorado (1990).

Meybeck et al., 2003 M. Meybeck, L. Laroche, H.H. Durr and J.P.M. Syvitski, Global variability of daily total suspended solids and their fluxes in rivers, Glob Planet Change 39 (2003), pp. 65-93.

Mimikou, 1990 M. Mimikou, Regional analysis of hydrological variables in Greece, Regionalisation in Hydrology, proceedings of the Ljubljana Symposium, IAHS Publication vol. 191 (1990) Wallingford, UK.

Morehead et al., 2003 M.D. Morehead, J.P. Syvitski, E.W.H. Hutton and S.D. Peckham, Modelling the temporal variability in the flux of sediment from ungauged river basins, Glob Planet Change 39 (2003), pp. 95-110

Nadal-Romero et al., 2007 E. Nadal-Romero, J. Latron, C. Martí-Bono and D. Regüés, Temporal distribution of suspended sediment transport in a humid Mediterranean badland area: the Araguás catchment, Central Pyrenees, Geomorphology 87 (2007), pp. 601-616.

Newcombe and Jensen, 1996 C. Newcombe and J.O. Jensen, Channel suspended sediment and fisheries, a synthesis for quantitative assessment of risk and impact, $N$ Am J Fish Manage 16 (1996), pp. 693-727.

Porterfield, 1972 G. Porterfield, Computation of fluvial-sediment discharge: U.S. Geological Survey Techniques of Water-Resources Investigations of the United States Geological Survey, Book 3, Chapter C2 (1972).

Quilbé et al., 2006 R. Quilbé, A.N. Rousseau, M. Duchemin, A. Poulin, G. Gangbazo and J.P. Villeneuve, Selecting a calculation method to estimate sediment and nutrient loads in streams: application to the Beaurivage River (Québec, Canada), J Hydrol 326 (2006), pp. 295-310.

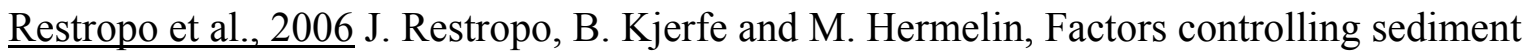
yield in a major south American drainage basin: the Magdalena river, Colombia, J Hydrol 316 (2006), pp. 213-232.

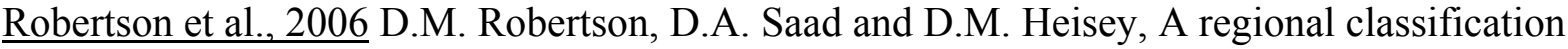
scheme for estimating reference water quality in streams using land-use-adjusted spatial regression-tree analysis, Environ Manage 32 (2006), pp. 209-229.

Rovira and Batalla, 2006 R. Rovira and R.J. Batalla, Temporal distribution of suspended sediment transport in a Mediterranean basin: the Lower Tordera (NE SPAIN), Geomorphology 79 (2006), pp. 58-71.

Siakeu et al., 2004 J. Siakeu, T. Oguchi, T. Aoki, Y. Esaki and H.P. Jarvie, Change in riverine suspended sediment concentration in central Japan in response to late 20th century human activities, Catena 55 (2004), pp. 231-254. 
Simon and Klimetz, 2008 A. Simon and L. Klimetz, Magnitude, frequency and duration relations for suspended sediment in stable ("reference") south-eastern streams, $J$ Am Water Resour Assoc 44 (2008), pp. 1270-1283.

Simon et al., 2004 A. Simon, W. Dickerson and A. Heins, Suspended-sediment transport rates at the 1.5-year recurrence interval for ecoregions of the United States: transport conditions at the bankfull and effective discharge?, Geomorphology 58 (2004), pp. 243-262.

Snoussi et al., 2002 M. Snoussi, S. Haida and S. Imassi, Effects of the construction of dams on the water and Moulouya and the Sebou rivers Morocco, Reg Environ Change 3 (2002), pp. $5-12$.

Soler et al., 2007a M. Soler, J. Latron and F. Gallart, Relationships between suspended sediment concentrations and discharge in two small instrumented basins in a mountain Mediterranean area (Vallcebre, Eastern Pyrenees), Geomorphology 71 (2007), pp. 164-171.

Soler et al., 2007b M. Soler, D. Regüés, J. Latron and F. Gallart, Frequency-magnitude relationships for precipitation, stream flow and sediment load events in a small Mediterranean basin (Vallcebre basin, Eastern Pyrenees), Catena 71 (2007), pp. 164-171.

Tramblay et al., 2008 Y. Tramblay, A. St-Hilaire and T.B.M.J. Ouarda, Frequency analysis of maximum annual suspended sediment concentrations in North America, Hydrol Sci J 53 (2008), pp. 236-252.

Tramblay et al., 2010 Y. Tramblay, T.B.M.J. Ouarda, A. St-Hilaire and J. Poulin, Regional estimation of extreme suspended sediment concentrations using watershed characteristics, $J$ Hydrol $\mathbf{3 8 0}$ (2010), pp. 305-317.

Van Sickle, 1982 J. Van Sickle, Stochastic predictions of suspended sediment yields from small coastal watersheds in Oregon, USA, J Hydrol 56 (1982), pp. 309-323.

Walling, 2006 D.E. Walling, Human impact on land-ocean sediment transfer by the world's rivers, Geomorphology 79 (2006), pp. 192-216.

Warrick et al., 2004 J.A. Warrick, L.A.K. Mertes, L. Washburn and D.A. Siegel, A conceptual model for river water and sediment dispersal in the Santa Barbara Channel, California, Cont Shelf Res 24 (17) (2004), pp. 2029-2043.

Waters, 1995 T.F. Waters, Sediments in streams: sources, biological effects and control, American Fisheries Society Monograph, no. 7, USA (1995).

Watts et al., 2003 C.D. Watts, P.S. Naden, D.M. Cooper and B. Gannon, Application of a regional procedure to assess the risk to fish from high sediment concentrations, Sci Total Environ 2003 (314-136) (2003), pp. 551-565.

Zabaleta et al., 2007 A. Zabaleta, M. Martíneza, J.A. Uriartea and I. Antigüedada, Factors controlling suspended sediment yield during runoff events in small headwater catchments of the Basque Country, Catena (2007), pp. 71,179-71,190.

\section{Figures and Tables}




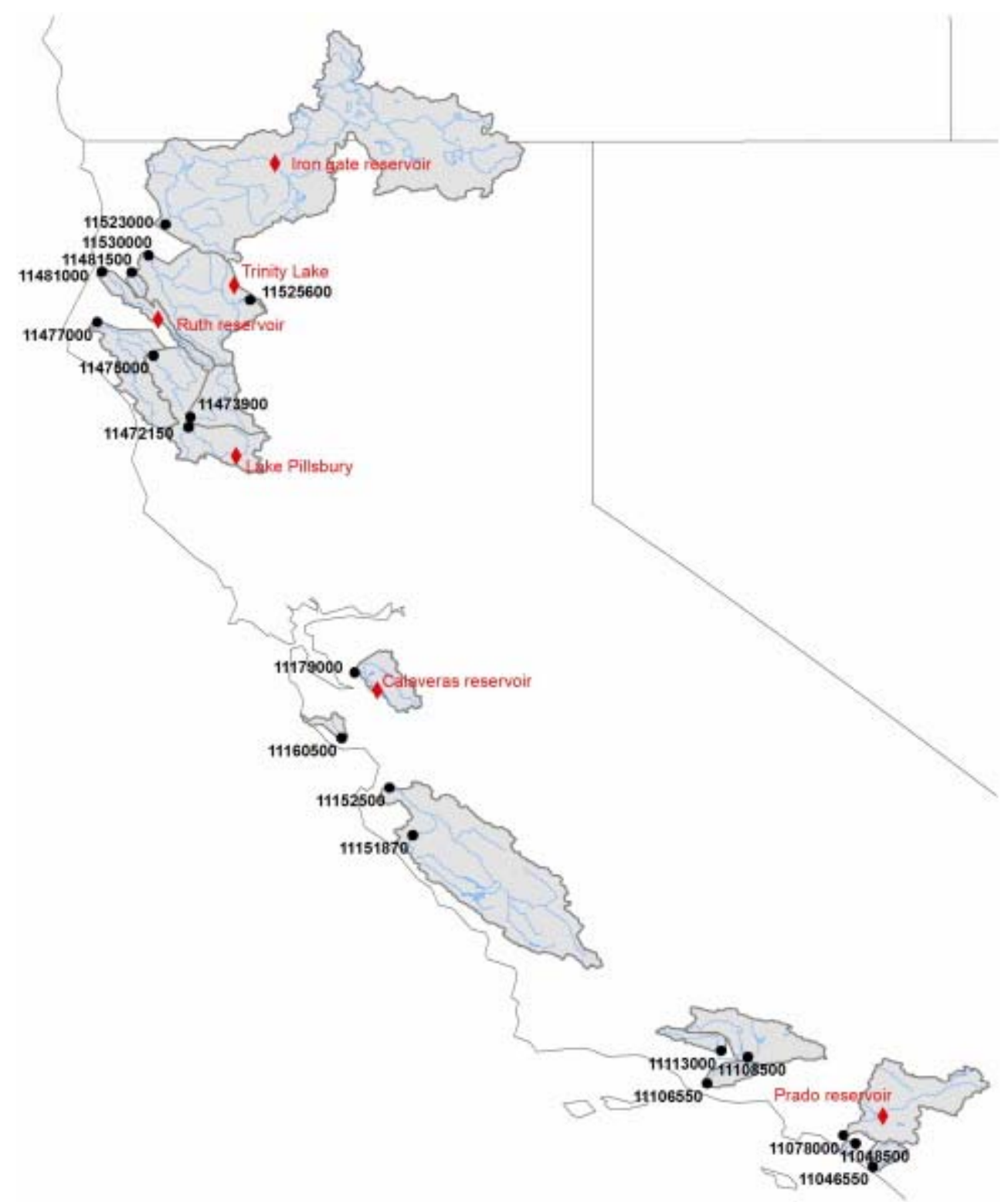

Fig. 1. Map of the selected watersheds.

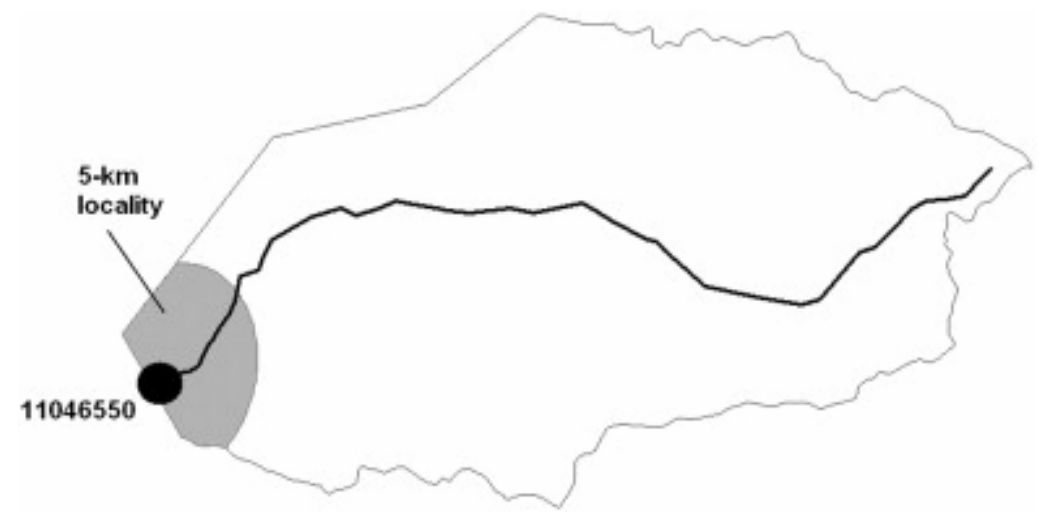

Fig. 2. Definition of the $5 \mathrm{~km}$ station-locality. 


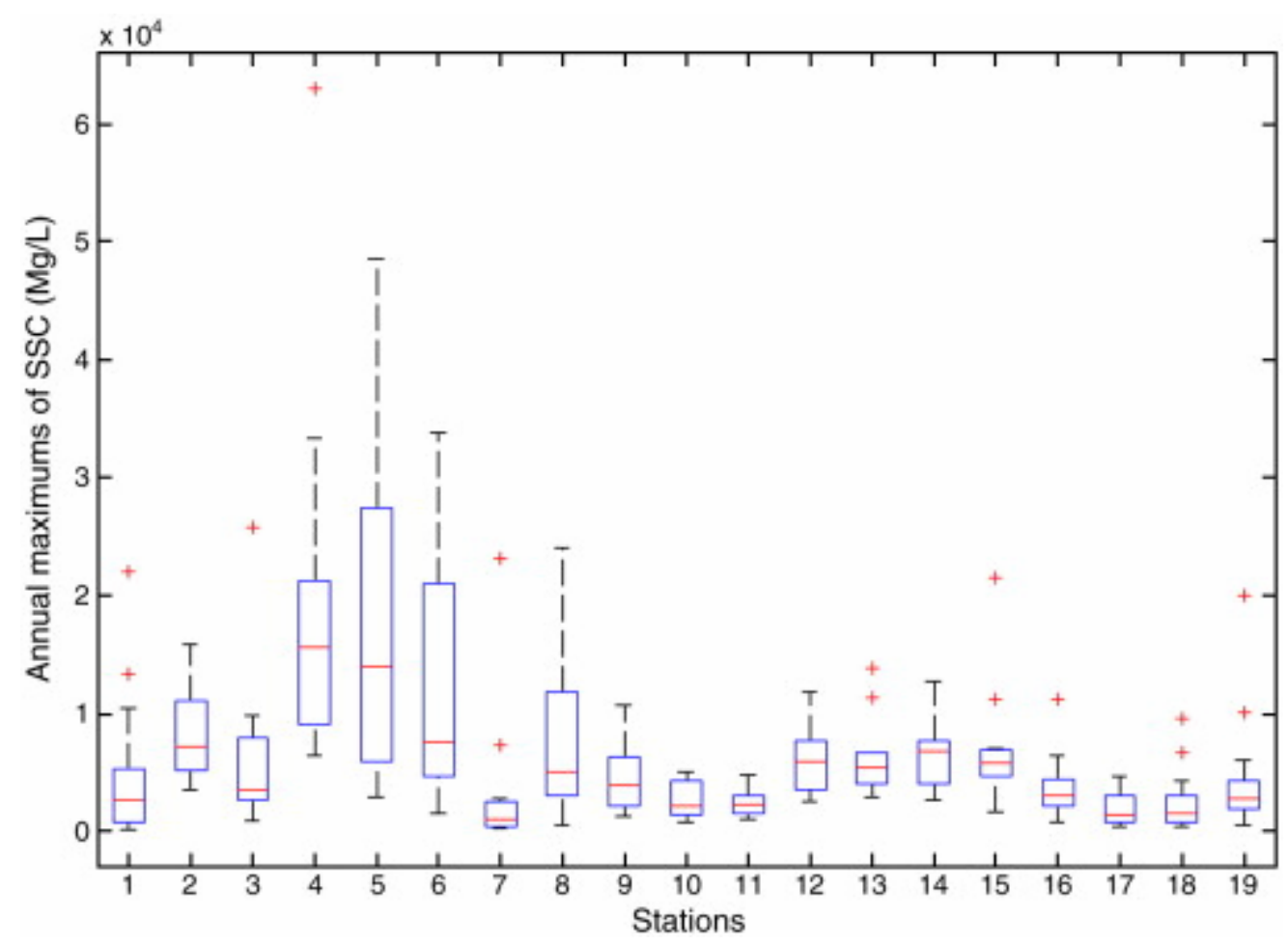

Fig. 3. Inter annual variability of annual maximum SSCs (box-plot displaying for each station the smallest observation, lower quartile, median, upper quartile, and largest observation). 
A

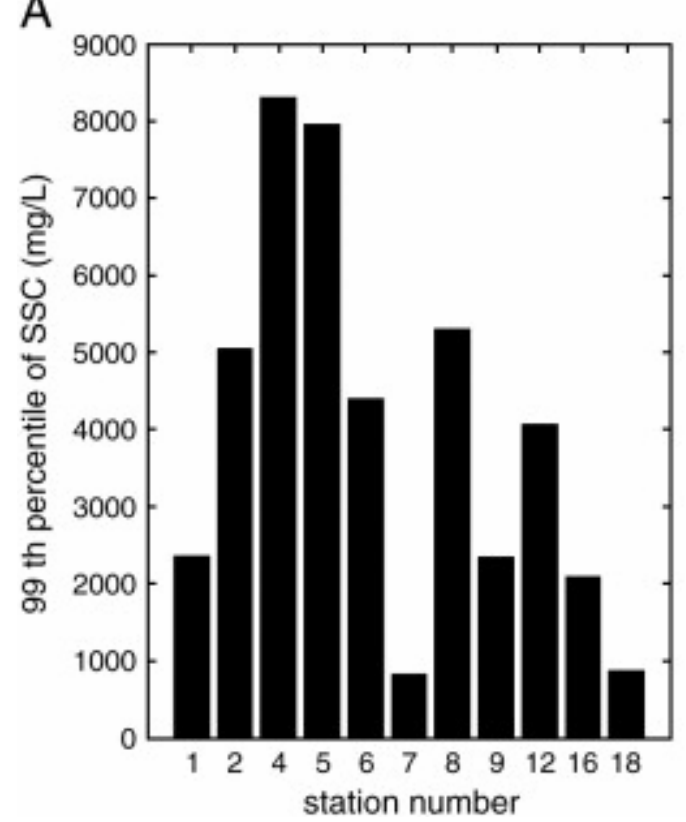

B

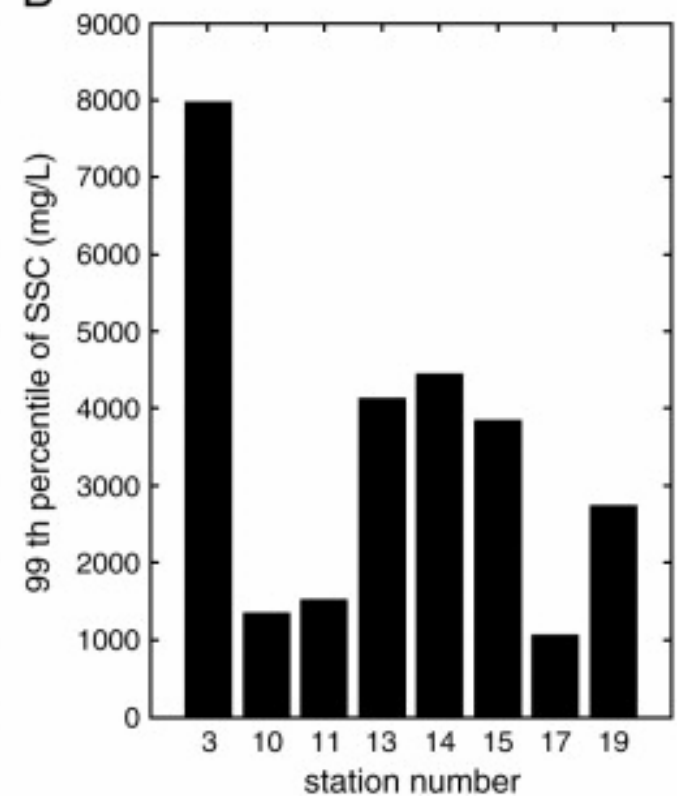

Fig. 4. 99th percentile of SSCs for sites with (A) or without (B) reservoirs on their main stem.
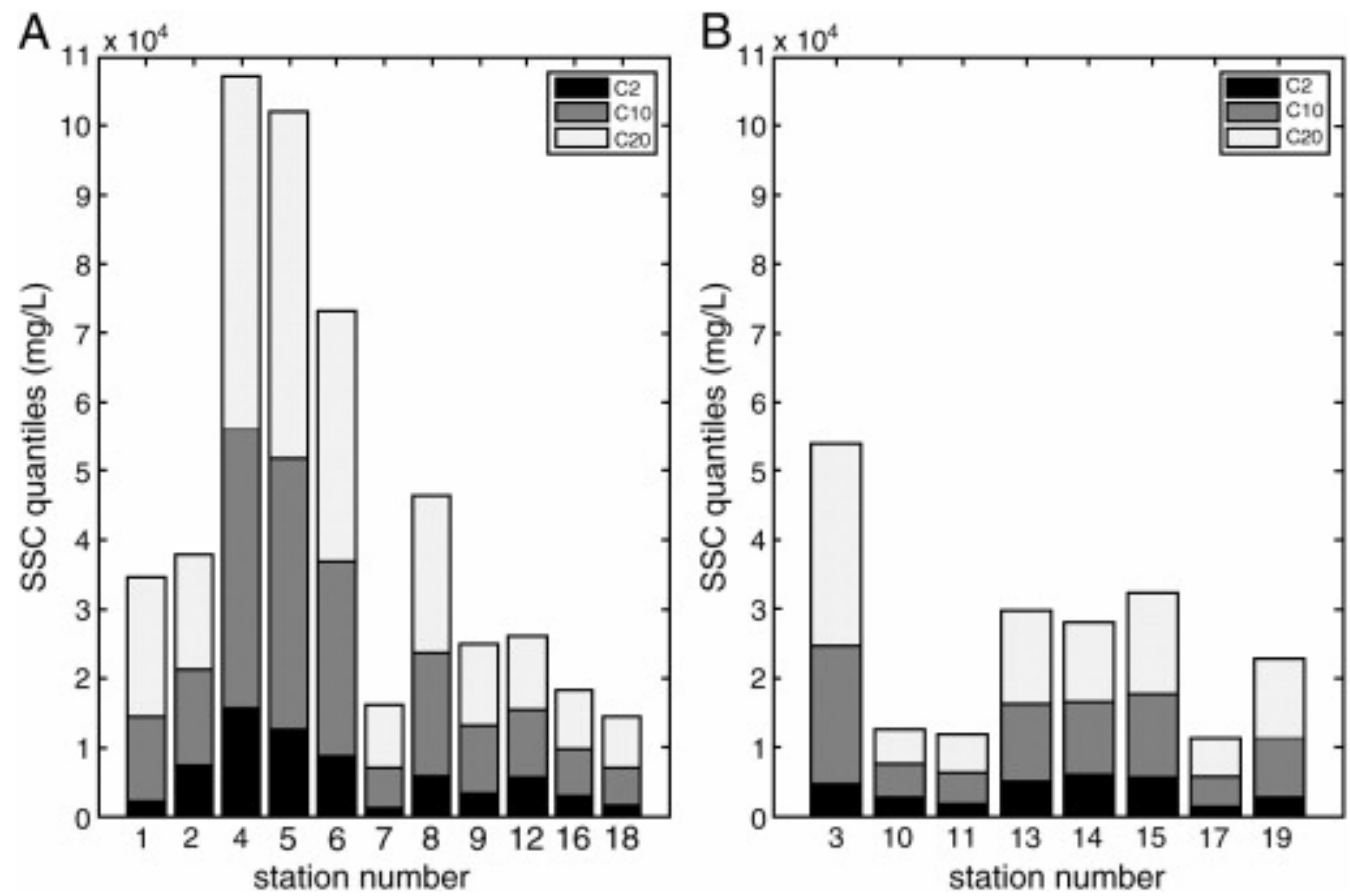

Fig. 5. SSC quantiles of return periods 2, 10 and 20 years (C2, C10 and C20) for sites with $(A)$ or without $(B)$ reservoirs on their main stem. 

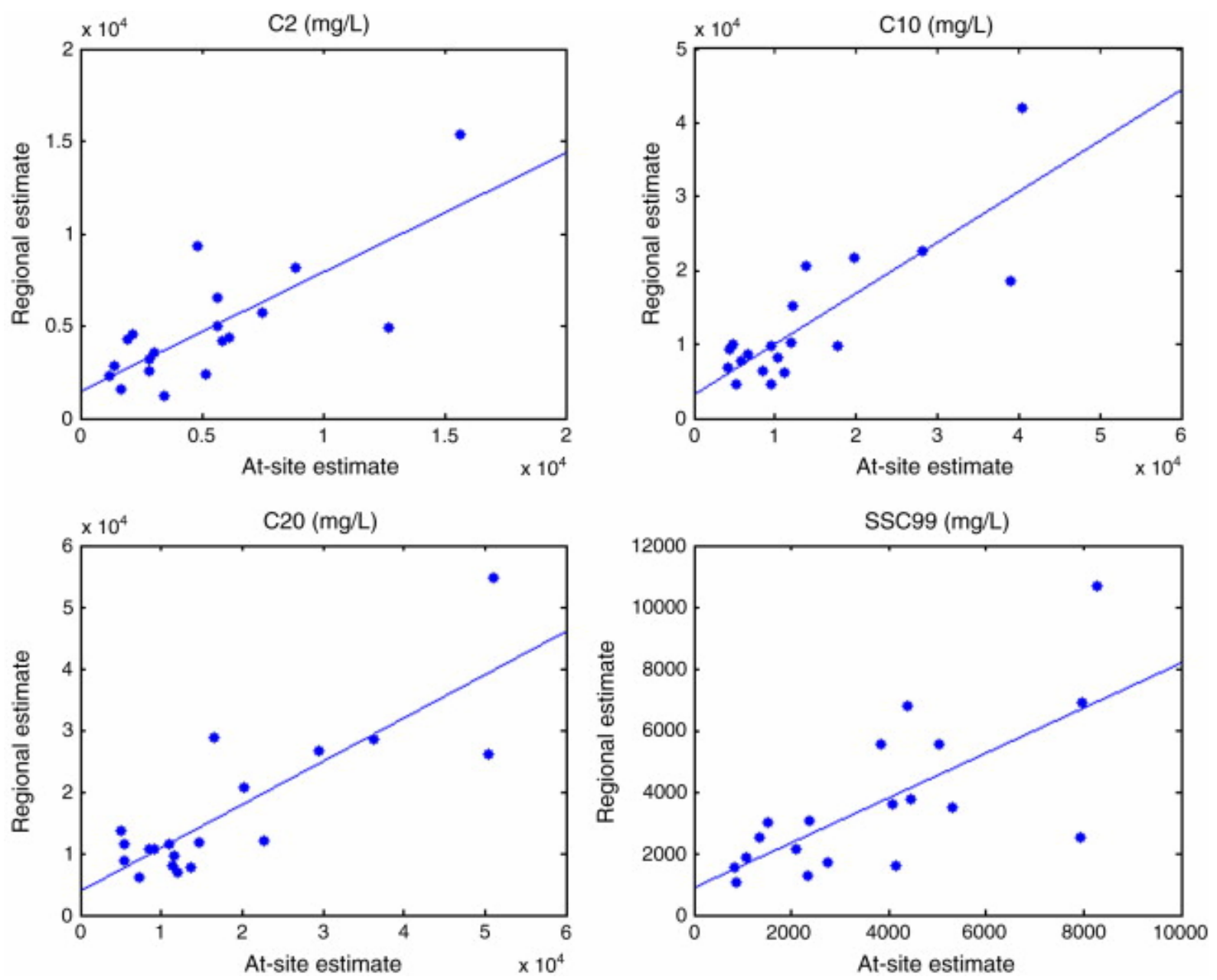

Fig. 6. Extreme SSC estimation results: regional estimates vs. at-site estimates.

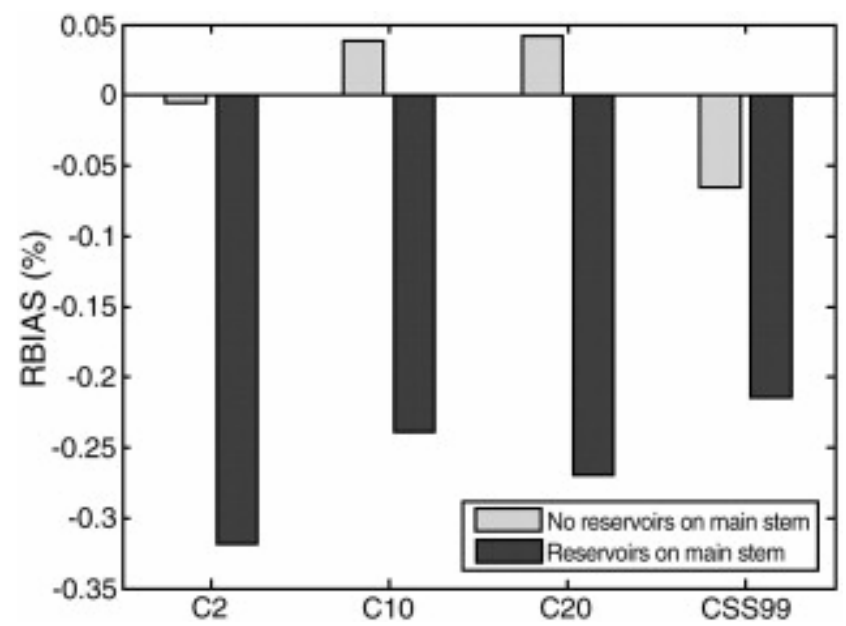

Fig. 7. Relative bias (RBIAS) for estimation results of extreme SSCs in the 19 sites. 


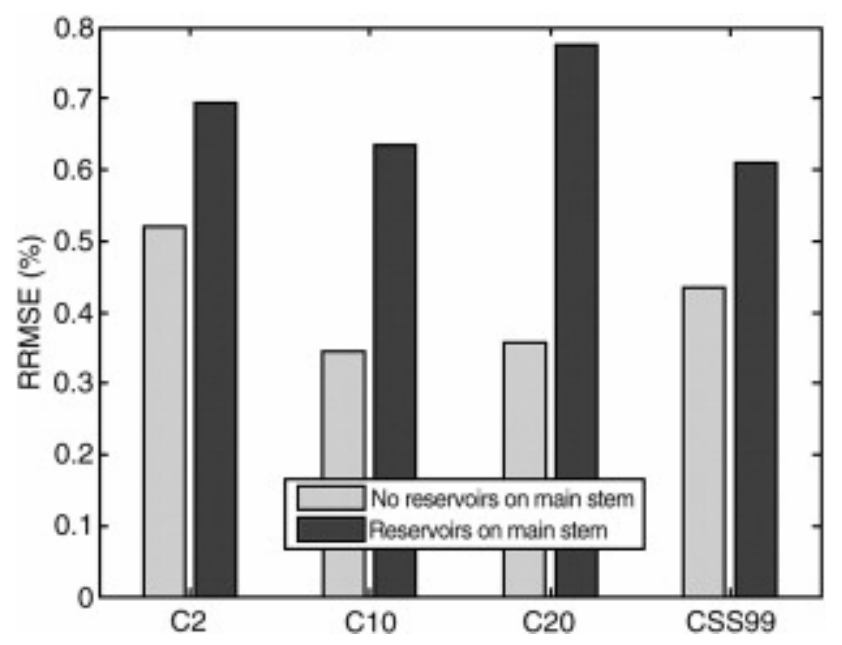

Fig. 8. Relative root mean square error (RRMSE) for estimation results of extreme SSCs in the 19 sites. 
Table 1. Selected stations.

\begin{tabular}{|c|c|c|c|c|c|c|c|c|c|c|}
\hline ID & $\begin{array}{l}\text { USGS } \\
\text { code }\end{array}$ & Lat & Lon & Name & $\begin{array}{l}\text { Size } \\
\left(\mathbf{k m}^{2}\right)\end{array}$ & $\begin{array}{l}\text { Mean } \\
\text { CSS } \\
(\mathrm{mg} / \mathrm{L})\end{array}$ & $\begin{array}{l}\text { Station } \\
\text { altitude } \\
\text { (m) }\end{array}$ & $\begin{array}{l}\text { Annual } \\
\text { precip. } \\
\text { (mm) }\end{array}$ & $\begin{array}{l}\text { Available } \\
\text { years }\end{array}$ & $\begin{array}{l}\text { Reservoirs } \\
\text { on main } \\
\text { stem }\end{array}$ \\
\hline 1 & 11046550 & 33.29 & -117.39 & $\begin{array}{l}\text { San Juan } \\
\text { Creek at } \\
\text { San Juan } \\
\text { Capistrano }\end{array}$ & 545 & 146.7 & 100 & 871.4 & $\begin{array}{l}1971- \\
1986\end{array}$ & - \\
\hline 2 & 11048500 & 33.40 & -117.48 & $\begin{array}{l}\text { San Diego } \\
\text { CR at } \\
\text { Culver DR } \\
\text { NR Irvine }\end{array}$ & 123 & 576.2 & 35 & 891.0 & $\begin{array}{l}1973- \\
1985\end{array}$ & - \\
\hline 3 & 11078000 & 33.44 & -117.54 & $\begin{array}{l}\text { Santa Ana } \\
\text { R A Santa } \\
\text { Ana }\end{array}$ & 4319 & 290.5 & 32 & 855.7 & $\begin{array}{l}1968- \\
1988\end{array}$ & $\begin{array}{l}\text { Prado } \\
\text { reservoir. } \\
32 \mathrm{~km} \\
\text { upstream }\end{array}$ \\
\hline 4 & 11106550 & 34.10 & -119.02 & $\begin{array}{l}\text { Calleguas C } \\
\text { Camarillo } \\
\text { State } \\
\text { Hospital }\end{array}$ & 638 & 616.0 & 75 & 915.4 & $\begin{array}{l}1968- \\
1978\end{array}$ & - \\
\hline 5 & 11108500 & 34.23 & -118.42 & $\begin{array}{l}\text { Santa Clara } \\
\text { R A Los } \\
\text { Angeles- } \\
\text { Ventura }\end{array}$ & 2937 & 215.0 & 415 & 906.9 & $\begin{array}{l}1968- \\
1978\end{array}$ & - \\
\hline 6 & 11113000 & 34.27 & -118.55 & $\begin{array}{l}\text { Sespe Creek } \\
\text { NR } \\
\text { Fillmore }\end{array}$ & 594 & 76.4 & 584 & 904.6 & $\begin{array}{l}1967- \\
1978\end{array}$ & - \\
\hline 7 & 11151870 & 36.14 & -121.29 & $\begin{array}{l}\text { Arroyo } \\
\text { Seco NR } \\
\text { Greenfield }\end{array}$ & 436 & 321.0 & 572 & 1084.5 & $\begin{array}{l}1963- \\
1984\end{array}$ & - \\
\hline 8 & 11152500 & 36.37 & -121.4 & $\begin{array}{l}\text { Salinas R } \\
\text { NR } \\
\text { Spreckels }\end{array}$ & 10,885 & 99.9 & 64 & 1053.5 & $\begin{array}{l}1969- \\
1979\end{array}$ & - \\
\hline 9 & 11160500 & 37.02 & -122.04 & $\begin{array}{l}\text { San } \\
\text { Lorenzo R } \\
\text { A Big Trees }\end{array}$ & 341 & 281.3 & 204 & 1130.4 & $\begin{array}{l}1972- \\
1982\end{array}$ & - \\
\hline 10 & 11179000 & 37.35 & -121.57 & $\begin{array}{l}\text { Alameda C } \\
\text { NR Niles }\end{array}$ & 1391 & 112.3 & 271 & 1135.6 & $\begin{array}{l}1960- \\
1973\end{array}$ & $\begin{array}{l}\text { Calaveras } \\
\text { reservoir. } \\
18 \mathrm{~km} \\
\text { upstream }\end{array}$ \\
\hline 11 & 11472150 & 39.37 & -123.2 & $\begin{array}{l}\text { Eel R NR } \\
\text { Dos Rios }\end{array}$ & 1724 & 56.8 & 556 & 1412.3 & $\begin{array}{l}1967- \\
1977\end{array}$ & $\begin{array}{l}\text { Lake } \\
\text { Pillsbury. } \\
49 \mathrm{~km} \\
\text { upstream }\end{array}$ \\
\hline 12 & 11473900 & 39.42 & -123.19 & $\begin{array}{l}\text { MF Eel R } \\
\text { NR Dos } \\
\text { Rios }\end{array}$ & 1739 & 360.2 & 654 & 1464.0 & $\begin{array}{l}1966- \\
1976\end{array}$ & - \\
\hline 13 & 11475000 & 40.13 & -123.38 & $\begin{array}{l}\text { Eel R A } \\
\text { Fort Seward }\end{array}$ & 5650 & 103.8 & 266 & 1475.6 & $\begin{array}{l}1966- \\
1976\end{array}$ & $\begin{array}{l}\text { Lake } \\
\text { Pillsbury. } \\
124 \text { km }\end{array}$ \\
\hline
\end{tabular}




\begin{tabular}{|c|c|c|c|c|c|c|c|c|c|c|}
\hline ID & $\begin{array}{l}\text { USGS } \\
\text { code }\end{array}$ & Lat & Lon & Name & $\begin{array}{l}\text { Size } \\
\left(\mathbf{k m}^{2}\right)\end{array}$ & $\begin{array}{l}\text { Mean } \\
\text { CSS } \\
(\mathrm{mg} / \mathrm{L})\end{array}$ & $\begin{array}{l}\text { Station } \\
\text { altitude } \\
\text { (m) }\end{array}$ & $\begin{array}{l}\text { Annual } \\
\text { precip. } \\
(\mathbf{m m})\end{array}$ & $\begin{array}{l}\text { Available } \\
\text { years }\end{array}$ & $\begin{array}{l}\text { Reservoirs } \\
\text { on main } \\
\text { stem }\end{array}$ \\
\hline & & & & & & & & & & upstream \\
\hline 14 & 11477000 & 40.293 & -124.06 & $\begin{array}{l}\text { Eel R A } \\
\text { Scotia }\end{array}$ & 8126 & 72.0 & 186 & 1528.1 & $\begin{array}{l}1960- \\
1980\end{array}$ & $\begin{array}{l}\text { Lake } \\
\text { Pillsbury. } \\
178 \mathrm{~km} \\
\text { upstream }\end{array}$ \\
\hline 15 & 11481000 & 40.54 & -124.03 & $\begin{array}{l}\text { Mad R NR } \\
\text { Arcata }\end{array}$ & 1109 & 272.4 & 79 & 1687.6 & $\begin{array}{l}1960- \\
1974\end{array}$ & $\begin{array}{l}\text { Ruth } \\
\text { Reservoir. } \\
84 \mathrm{~km} \\
\text { upstream }\end{array}$ \\
\hline 16 & 11481500 & 40.54 & -123.49 & $\begin{array}{l}\text { Redwood C } \\
\text { NR Blue } \\
\text { Lake }\end{array}$ & 218 & 348.9 & 573 & 1733.6 & $\begin{array}{l}1973- \\
1988\end{array}$ & - \\
\hline 17 & 11523000 & 41.18 & -123.32 & $\begin{array}{l}\text { Klamath } \\
\text { River at } \\
\text { Orleans }\end{array}$ & 21,558 & 317.1 & 478 & 1522.0 & $\begin{array}{l}1968- \\
1979\end{array}$ & $\begin{array}{l}\text { Iron Gate } \\
\text { reservoir. } \\
152 \mathrm{~km} \\
\text { upstream }\end{array}$ \\
\hline 18 & 11525600 & 40.4 & -122.5 & $\begin{array}{l}\text { Grass } \\
\text { Valley C } \\
\text { NR } \\
\text { Lewiston }\end{array}$ & 135 & 77.2 & 942 & 1600.3 & $\begin{array}{l}1976- \\
1994\end{array}$ & - \\
\hline 19 & 11530000 & 41.03 & -123.4 & $\begin{array}{l}\text { Trinity R A } \\
\text { Hoopa }\end{array}$ & 5244 & 275.4 & 351 & 1666.4 & $\begin{array}{l}1960- \\
1979\end{array}$ & $\begin{array}{l}\text { Trinity } \\
\text { Lake. } \\
135 \mathrm{~km} \\
\text { upstream }\end{array}$ \\
\hline
\end{tabular}


Table 2. Physiographic parameters.

\begin{tabular}{|c|c|c|}
\hline & Residential & High or low density residential \\
\hline \multirow[t]{8}{*}{ Landcover } & COMMERCIAL/IND. & Commercial or industrial \\
\hline & BARE ROCK & Bare rock/sand/clay \\
\hline & FOREST & Forest \\
\hline & SHRUBLAND & Shrubland \\
\hline & ORCHARD/VINE. & Orchards/vineyards/other \\
\hline & PASTURE/HAY & Pasture/hay \\
\hline & ROW CROPS & Row crops \\
\hline & SMALL GRAINS & Small grains \\
\hline \multirow[t]{6}{*}{ Topography } & MIN_ALT & Minimum altitude (m) \\
\hline & MAX_ALT & Maximum altitude (m) \\
\hline & MEAN_ALT & Mean altitude (m) \\
\hline & MEAN_SLOPE & Mean slope $(\%)$ \\
\hline & PERIMETER & Perimeter of drainage area $(\mathrm{km})$ \\
\hline & KM2 & Size of drainage area $(\mathrm{km} 2)$ \\
\hline \multirow[t]{7}{*}{ Climate } & PRCP1 & Days with precipitation (days) \\
\hline & PANNU & Precipitation total (mm) \\
\hline & SDII & Rainfall intensity (mm/day) \\
\hline & PDAYMAX & Maximum daily precipitation (mm) \\
\hline & SNOW & Mean depth of snow $(\mathrm{cm})$ \\
\hline & FROST & Number of frost days (days) \\
\hline & TJAN & Mean January temperature (deg. Celsius) \\
\hline \multirow[t]{6}{*}{ Soils } & KFFACT & $K$ factor \\
\hline & $\mathrm{OM}$ & Fraction of organic materials (\%) \\
\hline & PERM & Permeability of the soil (cm per hour) \\
\hline & THICK & Cumulative thickness of all soil layers $(\mathrm{cm})$ \\
\hline & DRAIN & Soil drainage group \\
\hline & ROCKVOL & Rock (> $2 \mathrm{~mm})$ volume on surface $(\%)$ \\
\hline
\end{tabular}




\begin{tabular}{|l|l|l|}
\hline & Residential & High or low density residential \\
\hline & F_SAND & Volume percent of sand $(\%)$ \\
\hline & F_SILT & Volume percent of silt $(\%)$ \\
\hline & F_CLAY & Volume percent of clay $(\%)$ \\
\hline & BD & Bulk density $\left(\mathrm{g} / \mathrm{cm}^{3}\right)$ \\
\hline & ROCKDEPTH & Mean depth to bedrock $(\mathrm{cm})$ \\
\hline & POROS & Soil porosity $(\%)$ \\
\hline
\end{tabular}


Table. 3 Spearman correlation coefficient (rho) between annual maximum SSCs and the corresponding discharge and the associated $P$-value $(*=$ stations with reservoirs on the main stem of the river).

\begin{tabular}{|l|l|l|}
\hline ID & $P$-value & rho \\
\hline 16 & 0.000 & 0.889 \\
\hline $17^{*}$ & 0.000 & 0.945 \\
\hline $19^{*}$ & 0.000 & 0.738 \\
\hline 6 & 0.002 & 0.855 \\
\hline 9 & 0.002 & 0.900 \\
\hline 2 & 0.008 & 0.806 \\
\hline 4 & 0.009 & 0.828 \\
\hline 12 & 0.018 & 0.745 \\
\hline $15^{*}$ & 0.029 & 0.591 \\
\hline 5 & 0.034 & 0.821 \\
\hline 1 & 0.060 & -0.515 \\
\hline $10^{*}$ & 0.122 & -0.610 \\
\hline $11^{*}$ & 0.133 & 0.515 \\
\hline $13^{*}$ & 0.178 & 0.467 \\
\hline $3^{*}$ & 0.366 & 0.287 \\
\hline $14^{*}$ & 0.381 & 0.212 \\
\hline 8 & 0.703 & 0.167 \\
\hline 18 & 0.906 & 0.038 \\
\hline 7 & 0.961 & 0.015 \\
\hline
\end{tabular}


Table 4. Spearman correlation coefficients between SSC indicators and station-locality characteristics (in bold the significant correlations at the 5\% level).

\begin{tabular}{|l|l|l|l|l|}
\hline \multicolumn{5}{|l}{ Correlations with station-locality characteristics } \\
\hline & $\mathbf{C 2}$ & $\mathbf{C 1 0}$ & $\mathbf{C 2 0}$ & SSC99 \\
\hline Residential & 0.276 & $\mathbf{0 . 5 7 4}$ & $\mathbf{0 . 5 7 1}$ & $\mathbf{0 . 5 5 9}$ \\
\hline Commercial/ind. & 0.206 & 0.408 & 0.432 & $\mathbf{0 . 4 5 6}$ \\
\hline Forest & $-\mathbf{0 . 4 8 1}$ & $\mathbf{- 0 . 7 1 4}$ & $\mathbf{- 0 . 6 7 2}$ & $\mathbf{- 0 . 6 1 2}$ \\
\hline Shrubland & 0.286 & $\mathbf{0 . 4 8 6}$ & $\mathbf{0 . 5 0 4}$ & 0.237 \\
\hline Orchard/vine. & $\mathbf{0 . 6 2 7}$ & $\mathbf{0 . 6 2 7}$ & $\mathbf{0 . 6 2 7}$ & $\mathbf{0 . 4 9 3}$ \\
\hline Pasture/hay & $\mathbf{0 . 5 2 5}$ & $\mathbf{0 . 5 2 5}$ & $\mathbf{0 . 5 2 5}$ & $\mathbf{0 . 5 4 5}$ \\
\hline Row crop & $\mathbf{0 . 6 4 9}$ & $\mathbf{0 . 7 4 8}$ & $\mathbf{0 . 7 4 2}$ & $\mathbf{0 . 6 3 2}$ \\
\hline Small grains & $\mathbf{0 . 5 0 3}$ & $\mathbf{0 . 5 0 3}$ & $\mathbf{0 . 5 0 3}$ & 0.385 \\
\hline MIN_ALT & -0.393 & $\mathbf{- 0 . 5 1 4}$ & $\mathbf{- 0 . 5 1 5}$ & $\mathbf{- 0 . 5 1 9}$ \\
\hline MAX_ALT & -0.453 & $\mathbf{- 0 . 6 0 2}$ & $\mathbf{- 0 . 5 7 2}$ & $\mathbf{- 0 . 6 5 1}$ \\
\hline MEAN_ALT & -0.379 & $\mathbf{- 0 . 5 3 0}$ & $\mathbf{- 0 . 5 4 2}$ & $\mathbf{- 0 . 6 1 1}$ \\
\hline MEAN_SLOPE & $-\mathbf{0 . 5 0 2}$ & $-\mathbf{0 . 6 3 0}$ & $\mathbf{- 0 . 6 1 4}$ & $\mathbf{- 0 . 6 8 4}$ \\
\hline TJAN & 0.454 & $\mathbf{0 . 7 0 4}$ & $\mathbf{0 . 6 9 6}$ & $\mathbf{0 . 5 7 4}$ \\
\hline PANNU & $-\mathbf{0 . 4 5 6}$ & $\mathbf{- 0 . 6 8 2}$ & $\mathbf{- 0 . 6 6 8}$ & $\mathbf{- 0 . 5 3 3}$ \\
\hline FROST & -0.235 & $\mathbf{- 0 . 4 5 6}$ & $\mathbf{- 0 . 4 6 5}$ & -0.358 \\
\hline PRCP1 & -0.300 & $\mathbf{- 0 . 5 8 9}$ & $\mathbf{- 0 . 5 8 9}$ & -0.418 \\
\hline PERM & 0.256 & 0.439 & $\mathbf{0 . 5 1 2}$ & 0.304 \\
\hline DRAIN & 0.453 & 0.379 & 0.302 & $\mathbf{0 . 5 5 3}$ \\
\hline ROCKVOL & $-\mathbf{0 . 6 4 0}$ & $\mathbf{- 0 . 6 6 3}$ & $\mathbf{- 0 . 6 1 2}$ & $\mathbf{- 0 . 7 3 7}$ \\
\hline & & & \\
\hline
\end{tabular}


Table 5. Estimation results for SSCs (all sites).

\begin{tabular}{|l|l|l|l|l|}
\hline & C2 & C10 & C20 & SSC99 \\
\hline RBIAS & $-13.8 \%$ & $-7.8 \%$ & $-8.9 \%$ & $-12.8 \%$ \\
\hline RRMSE & $60.0 \%$ & $48.8 \%$ & $57.1 \%$ & $51.5 \%$ \\
\hline$R^{2}$ & 0.68 & 0.72 & 0.70 & 0.69 \\
\hline
\end{tabular}

